Elsevier required licence: (C) <2021>. This manuscript version is made available under the CC-BY-NCND 4.0 license http://creativecommons.org/licenses/by-nc-nd/4.0/

The definitive publisher version is available online at

[https://www.sciencedirect.com/science/article/abs/pii/S0301421521002019?via\%3Dihub] 
Energy Policy

Volume 155, August 2021, 112331

https://doi.org/10.1016/j.enpol.2021.112331

\section{Explaining the slow progress of coal phase-out: The case of Guangdong- Hong Kong-Macao Greater Bay Region}

Peng Wang ${ }^{\mathrm{a}}$, Muyi Yang ${ }^{\mathrm{b}, \mathrm{d}^{*}}$, Kristy Mamaril ${ }^{\mathrm{b}}$, Xunpeng Shic, ${ }^{\mathrm{c}, \mathrm{d}}$, Beibei Cheng ${ }^{\mathrm{a}}$, and Daiqing $\mathrm{Zhao}^{\mathrm{a}}$

${ }^{a}$ Guangzhou Institute of Energy Conversion, Chinese Academy of Sciences, No. 2 Nengyuan Road, Guangzhou, 510640, China

${ }^{\mathrm{b}}$ Faculty of Engineering and IT, University of Technology Sydney, Sydney, Australia

${ }^{c}$ Australia-China Relations Institute, University of Technology Sydney, Sydney, Australia

d Australian Energy Transition Institute, Sydney, Australia

*Corresponding author

E-mail address: muyi.yang@uts.edu.au (M.Yang) 
Abstract: Prompted by the urgency of climate change, this paper analyses the impediments for coal phase-out, by using the Greater Bay Region in China as a case study. Rather than factors specific to coal production, transport and consumption (e.g., subsidies, and vested interests), as suggested by existing literature, the analysis of this paper demonstrates that coal phase-out in the region has encountered a range of market (e.g., high gas price), infrastructure (such as, inadequate network), and regulatory (e.g., prolonged project approval) impediments; these impediments have hindered the effective deployment of alternative energy sources, raising concern about coal phase-out and its crippling impacts on the security of energy supply. Redressing these impediments is therefore a key priority for promoting a smooth coal phaseout in the region. This requires a mix of policies addressing two dimensions: 1) those aimed at squeezing out coal from the energy-mix to create room for alternative low-carbon energy sources; and 2) those aimed at supporting the uptake of these sources. Implementing these policies is however a challenging task as it relies on close-centre-local, and inter- and intraregional cooperation, especially in a resource-poor region with a disperse energy endowment. Achieving this is difficult because the energy policy process of the country has long been characterised by fragmented authority and territorial administrative divisions with a proclivity for local governments to work in isolation from each other.

Keywords: Energy transition; Coal phase-out; Energy security; Guangdong; Hong Kong; Macao

\section{Introduction}

Fossil fuels have historically dominated the global energy technology-fuel mix. While they have contributed to the provision of cheap and reliable energy and consequently to socioeconomic prosperity, fossil fuels have also made the energy sector the largest emitter of greenhouse gases (GHG), and hence the major contributor to global warming - one of the most pressing challenges of our times (Elias, 2018; Yang et al., 2019). Redressing this challenge has, therefore, become a top policy priority and among various options under consideration, a broad consensus seems to have been reached that an attractive option is to phase out the use of coal and replace it with low-carbon energy sources (such as, solar, and wind). The attractiveness of coal phase-out is manifested in a more than $60 \%$ decrease in coal power investment worldwide over the period 2007-2018, from $\$ 143$ billion in 2007, to less than $\$ 60$ billion in 2018. The same period also witnessed an almost three-fold increase in global renewable investment from $\$ 122$ billion in 2007, to over $\$ 300$ billion in 2018 (IEA, 2019c). 
Nonetheless, the overall progress of coal phase-out has been slow, and in the absence of additional efforts, this trend is likely to continue in the years to come. As estimated by the International Energy Agency, for example, under a Current Policies Scenario, a continuation of existing energy policies that have already been put in place in the form of legislation or national and global agreements would see a modest reduction in the share of coal generation over the period 2018-2040, from $38 \%$ in 2018, to $25 \%$ in 2040 (IEA, 2019d). This is incompatible with the Paris Agreement to maintain the increase in global average temperature well below $2.0^{\circ} \mathrm{C}$, which requires a more drastic reduction in coal generation to about 2,400 TWh by 2040 , representing about $6 \%$ of total generation (IEA, 2019d). An even further phaseout of coal would be required to limit the global temperature increase to $1.5^{\circ} \mathrm{C}$ : an $80 \%$ reduction in coal generation by 2030 (compared with 2010 levels) and a complete phase-out of coal before 2040 (Parra et al., 2019).

Existing policy debate tends to attribute the slow progress of coal phase-out to factors specific to coal production, transportation, and consumption. Some of the key causes are: a) subsidies (such as, budget transfers, and tax breaks) to the production and consumption of coal, which have improved its cost-competitiveness as compared with other energy sources (Skovgaard and van Asselt, 2018; Xiang and Kuang, 2020; Yuan et al., 2019); b) strong resistance from fossil fuel incumbents (such as, public utility, and coal companies) whose interests are deeply embedded in the status quo (Hudson, 2019; Oxenaar and Bosman, 2020; Rentier et al., 2019); and c) concern about socio-economic losses (e.g., job and revenue losses) that may arise from coal phase-out (Gass and Echeverria, 2017; Shi et al., 2019; Wang et al., 2020a).

Such coal-centric focus for understanding causes (reasons) for the slow progress of coal phaseout - this paper contends - is deficient, because it fails to recognise that the energy system is complex and comprises multiple elements including, for example, technologies, knowledge, markets, infrastructures, and supply and distribution chains (Geels and Schot, 2007). These elements constitute an 'industry regime', where they interact with each other in a range of competing or complementary relationships, to ensure the functioning of the larger socioeconomic system, by providing reliable, good-quality and affordable energy (Geels, 2014). As such, a major change in a system element (coal phase-out, in our instance) would require changes in other relevant elements. Otherwise, the overall performance of the energy system would be undermined, which could in turn impede the progress of coal phase-out (Markard, 2018; Markard and Hoffmann, 2016). 
It is therefore plausible to argue that the existing coal-centric focus is unlikely to provide, on its own, sufficient insights into the causes (reasons) for the slow progress of coal phase-out, and hence bases for designing measures to rectify the situation. Such insights can only be gained if one is able to identify the systemic impediments for coal phase-out. It is based on these insights that more effective policies can be designed to promote coal phase-out, especially to the extent considered essential for redressing the climate change challenge.

Against the above backdrop, the main purpose of this paper is to develop an analysis of coal phase-out, with a view to identifying the broader systemic issues that have impeded its progress. The case-in-point for this analysis is provided by the Guangdong-Hong Kong-Macao Greater Bay Region of China (thereafter the Greater Bay Region, or GBR). The GBR does not have a local coal industry and completely relies on imported coal to satisfy its energy needs. Coal is also more expensive in the region than other regions in China, mainly because of high transportation costs (Shi et al., 2018). Together, this means that coal-specific factors have limited influence on shaping the progress of coal phase-out in the region. The selection of the region should therefore enable an interesting case study to be developed on how the progress of coal phase-out would be affected by a broader set of systemic issues.

This paper is organised as follows. Section 2 provides a contextual backdrop for the Greater Bay Region. Section 3 outlines the methodology adopted in the paper. Section 4 analyses key systemic issues of coal phase-out in the Greater Bay Region. Section 5 provides some further reflection on this analysis. Section 6 presents the main conclusions. Some key insights for policymakers are also discussed in this section.

\section{The Greater Bay Region: A contextual backdrop}

The Greater Bay Region is a city cluster in South China, which comprises nine cities in Guangdong's Pearl River Delta, as well as Hong Kong and Macao (see Figure 1). It is one of the most dynamic and fast-growing economic regions in China. Although the Greater Bay Region covers less than 1 per cent of China's land area, and is home to less than 5 per cent of the country's population, its combined GDP was $\$ 1.53$ trillion in 2017, which is equivalent to nearly 14 per cent of China's national GDP, and is comparable to the world's tenth largest economy - Canada (PWC, 2017). The region is endowed with limited energy resources, both renewable and non-renewable, and is almost completely reliant on imports to satisfy its energy needs. Coal has historically occupied a central place in the energy supply-mix of the region, accounting for about 60 per cent of primary energy supply, and more than 65 per cent of domestically-produced electricity (Guangdong Bureau of Statistics, 2019). 


\section{Figure 1: Location of the Greater Bay Region}

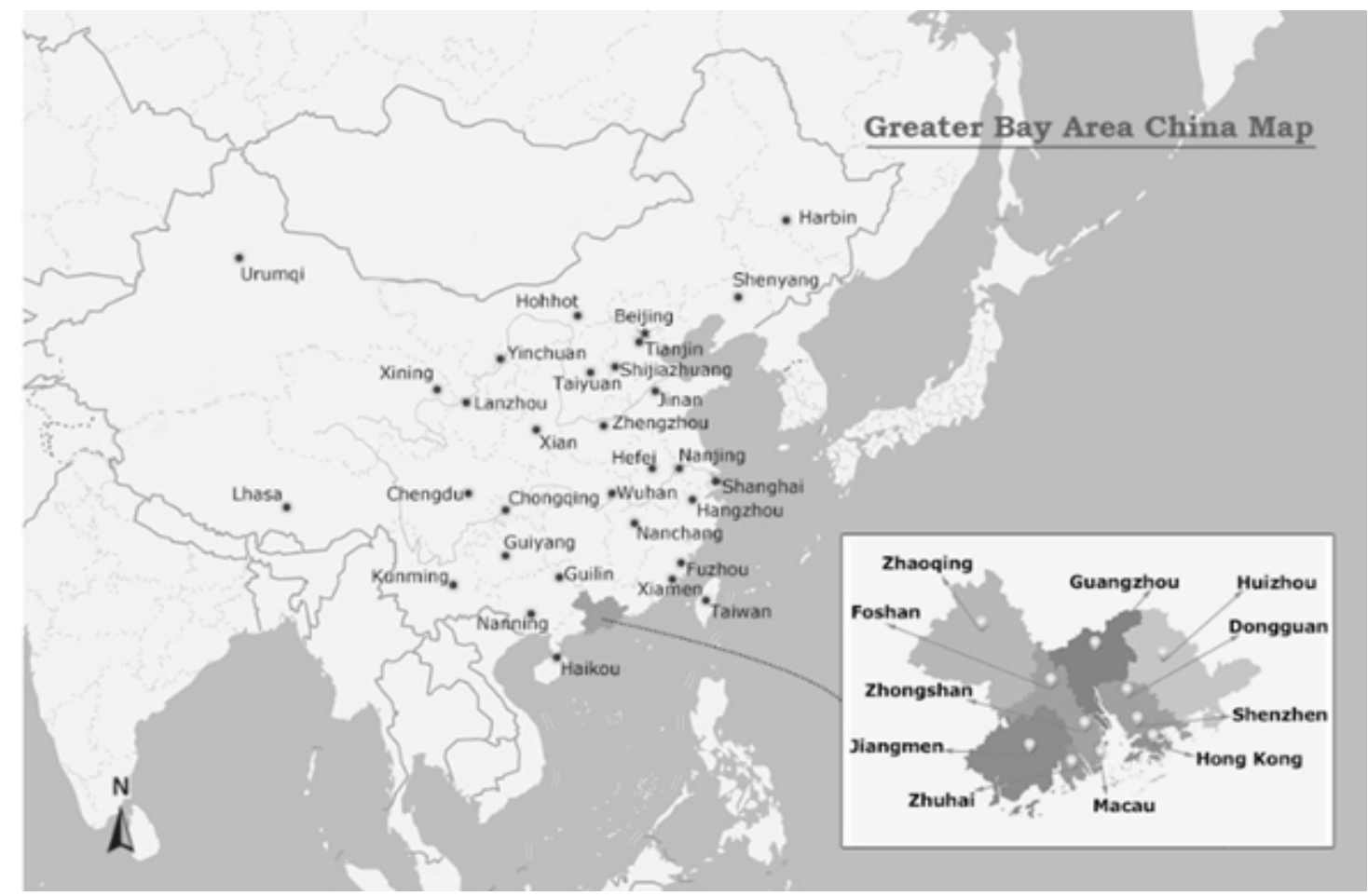

Some efforts have been made in the past few years to limit the growth of coal consumption in the region, following the introduction of the concept of ecological civilisation into the constitution in 2018, which serves as a guiding principle for the country's development towards a green and prosperous future, and has significant influence on shaping the energy policies and plans (Hansen et al., 2018). High air quality and low GHG emissions are considered as important aspects of ecological civilisation. Rising coal consumption is therefore perceived by the government as a potential threat to ecological civilisation (Feng et al., 2019). As a result, the central government's core policy goal for the development of the energy sector has been to control and limit coal consumption and this was given further credence and immediacy by the public outcry at the worsening air pollution in some of the major cities of the country. In 2014, the State Council issued the National Energy Development Strategy Plan (2014-2020), which clearly states that the total coal consumption will be capped at about 4.2 billion tons by 2020 , and the share of coal in primary energy consumption will be controlled at below $62 \%$ by 2020 (Fei, 2018). In 2017, the National Energy Administration released the $13^{\text {th }}$ Five-Year Plan on Energy Development, which re-affirms the country's commitment to squeezing out coal's share in energy mix and replacing it with non-fossil fuels and gas (Ma, 2017). In addition, several central policies have also been introduced as an integral part of the wider 'supply-side structural reform', aimed at reducing the excessive production capacity of coal (Shi et al., 2019; Shi et al., 2020; Wang et al., 2020b). 
Consistent with the central policies and plans, the Guangdong province made its own $13^{\text {th }}$ fiveyear plan on energy development, where annual coal consumption is capped at $0.175 \mathrm{Gt}$, and the share of coal in energy consumption is targeted to be reduced from $40.5 \%$ in 2015 to $36.9 \%$ in 2020 (see Table 1). In 2014, the governments of Guangdong, Hong Kong, and Macao signed a joint agreement to foster tripartite cooperation on air pollution control and prevention, and improve air quality in the region, where reducing the use of coal is considered as one of the key actions (EPD, 2014). The commitment to improving air quality was re-affirmed by the release of the Outline Development Plan for the Guangdong-Hong Kong-Macao Greater Bay Area in 2019, which attaches higher priority to 'building a quality living environment that is suitable for residents as well as business and tourism' (KPMG, 2019).

Hong Kong and Macao are Special Administrative Regions (SARs) of China and enjoy high degree of autonomy in making their own policy decisions (Holley and Lecavalier, 2017). In Hong Kong, the SAR government introduced the Climate Change Action Plan in 2017, with the target of reducing emissions intensity by 2030 , by $65 \%$ to $70 \%$ (compared with 2005 level). The Plan also outlined the actions to be undertaken for achieving the target, including to gradually phase down coal for electricity generation, which accounted for $48 \%$ of electricity generated in Hong Kong in 2015 (Environment Bureau, 2017). In Macao, phasing out the use of coal for electricity generation has however had limited attention. This is because Macao does not have any local coal generation; apart from a small amount of electricity generated locally from heavy oil, natural gas, and municipal solid waste. Almost all electricity consumed in Macao is imported from mainland China (Song et al., 2017).

For implementing the above-noted policies and plans, the GBR local governments have actively advocated coal phase-out, which involves the replacement of inefficient and highly polluting coal boilers in the industrial sector with cleaner-burning gas boilers or combined heat and power (CHP) plants, and the closure of less-efficient coal-fired power units (CornotGandolphe, 2019; Mirae Asset, 2020). These efforts have delivered some positive outcomes. For example, according to a climate monitoring bulletin jointly complied by the Guangdong Meteorological Service, the Hong Kong Observatory and the Macao Meteorological and Geophysical Bureau, the air quality of the GBR improved in 2018, with 1 to 11 fewer hazy days in various localities, as compared with the previous year (State Council, 2019). Besides, the GBR also witnessed a steady improvement in its emissions intensity, which was estimated at approximately 1.0 tons per 1,000 RMB in 2016 - about 70\% lower than the national average (Zhou et al., 2018). 
Despite these positive signs, promoting coal phase-out in the GBR, like other countries and regions in the world, remains a difficult task, especially to the extent that could be considered adequate for redressing the climate change challenge. This is especially true if one notes that China has recently relaxed restrictions on coal capacity expansion, raising concerns that more coal capacity would be constructed (Myllyvirta et al., 2020). A low-carbon transition of the energy sector, however, cannot be achieved in China without a rapid and orderly phase-out of coal, which is currently responsible for over $80 \%$ of energy-related $\mathrm{CO}_{2}$ emissions (IEA, 2019a). There is therefore an immediate need for developing some insights into the systemic impediments during the phase-out of coal in the country.

Table 1: Key energy targets in the $13^{\text {th }}$ Five-Year Plan

\begin{tabular}{|c|c|c|c|c|c|}
\hline & \multicolumn{2}{|c|}{ National } & \multicolumn{2}{|c|}{ Guangdong province } \\
\hline & & $\begin{array}{c}2015 \text { actual } \\
\text { levels }\end{array}$ & 2020 target & $\begin{array}{c}2015 \text { actual } \\
\text { levels }\end{array}$ & 2020 target \\
\hline \multirow{3}{*}{  } & Total (Gtce) & 4.3 & $<5.0$ & 0.301 & 0.338 \\
\hline & Coal (Gt) & 3.96 & 4.10 & 0.175 & 0.175 \\
\hline & Electricity (TWh) & 5,690 & $6,800 \sim 7,200$ & 531 & 670 \\
\hline \multirow{4}{*}{ 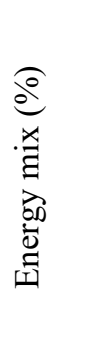 } & Non-fossil fuel installed capacity & 35 & 39 & 26 & 35 \\
\hline & $\begin{array}{l}\text { Non-fossil fuel in energy } \\
\text { consumption }\end{array}$ & 12 & 15 & 20 & 26 \\
\hline & Gas consumption & 5.9 & 10 & 8.3 & 12.0 \\
\hline & Coal consumption & 64 & 58 & 40.5 & 36.9 \\
\hline \multicolumn{2}{|c|}{ Energy intensity } & $\mathrm{N} / \mathrm{A}$ & $\begin{array}{l}-15 \% \text { from } \\
2015 \text { level }\end{array}$ & N/A & $\begin{array}{l}-17 \% \text { from } \\
2015 \text { level }\end{array}$ \\
\hline \multicolumn{2}{|c|}{ Emissions intensity } & $\mathrm{N} / \mathrm{A}$ & $\begin{array}{l}-18 \% \text { from } \\
2015 \text { level }\end{array}$ & $\mathrm{N} / \mathrm{A}$ & $\begin{array}{c}-20.5 \% \text { from } \\
2015 \text { level }\end{array}$ \\
\hline
\end{tabular}

Notes: Gtce $=$ Giga tonnes of coal equivalent; $\mathrm{Gt}=$ Giga tonnes; energy intensity $=$ energy consumption per unit of GDP; emissions intensity = GHG emissions per unit of GDP; N/A = not available.

Source: Developed by the authors based on a review of the $13^{\text {th }}$ FYP for energy sector development.

\section{Methodology}

This section reviews existing literature on the analysis of low-carbon energy transition, and informed by insights gained from the review, outlines the methodology employed in the paper. 


\subsection{Literature review}

In the broadest sense, low-carbon energy transition is defined in the literature as a paradigm shift away from the current fossil fuels-based energy systems, towards more efficient lowercarbon systems (Diji, 2019). Considerable work has already been undertaken to identify factors that may impede the progress of low-carbon energy transition (including, coal phase-out). Some of the earlier work view energy transition as a technological challenge, requiring either incremental or disruptive innovations in how energy is produced, transported and consumed (Henderson and Newell, 2010; LaBelle and Horwich, 2017; Seba, 2014). Based on this view, various studies have been conducted to analyse issues that may propel or impede the development of an innovation or set of innovations to decarbonise the energy sector. These issues include, for example, effectiveness of business models and strategies taken by firms to bring a low-carbon innovation to the market (Boons and Ludeke-Freund, 2013; Loorbach et al., 2010), market and regulatory changes required to facilitate a successful low-carbon innovation (Bakker, 2014; Bohnsack et al., 2016), incumbency effects on obstructing or promoting low-carbon innovations (Dijk et al., 2016; Lauber and Jacobsson, 2016; Smink et al., 2015), and technical and economic potentials of various low-carbon technologies (Moriarty and Honnery, 2012).

More recent work appears to have a broader conceptualisation of energy transition, viewing it as complex and long-term processes, which involve deep-structural changes in the overall configuration of the energy system. These entail changes in, for example, technologies, public policies, market rules, infrastructures, and consumer practices (Geels, 2011; Kemp et al., 2001). Here, the main focus of the analyses is on a broader set of systemic issues that may hinder energy transition towards increased use of low-carbon technologies. These issues include, for example, the dynamics of co-evolution between niche-innovations and incumbent regimes (Hess, 2016), and path-dependency and system lock-in (Aklin and Urpelainen, 2013; Klitkou et al., 2015). There has also been a growing interest in the governance aspect of energy transition, i.e., the process of policy making and implementation to promote system changes required for driving low-carbon energy transition (Kern and Rogge, 2018). This interest has arisen from increasing recognition of the critical role of governance in facilitating low-carbon transition of the energy system (Smith et al., 2005), and more importantly, the urgency of accelerating the current pace of energy decarbonisation in the face of the impending threat of climate change (Kern and Rogge, 2016; Sovacool, 2016). This interest has produced an emerging field of energy transition research on power structure and associated interests 
(Avelino and Grin, 2017; Lockwood et al., 2016), the politics of the policy process (Markard et al., 2016; Normann, 2015), and so on.

The above discussion suggests a growing recognition in the literature of the inherent complexity of the energy system, where various elements (such as, technologies, markets, and infrastructure) interact with each other in an array of competing or complementary relationship, to ensure the supply of reliable and sufficient energy at affordable prices (Geels, 2014). Therefore, to make change in one system element (coal phase-out, in our instance) would inevitably require changes to be made in other relevant elements, for example, deployment of alternative energy sources, supported by favourable market conditions and necessary infrastructure. If not, the overall functioning of the energy system would be undermined, which would in turn hinder the progress of coal phase-out (Markard, 2018; Markard and Hoffmann, 2016). Further, the complexity of the energy system is context-specific, varying across time and countries, because of 'different societal values, political systems and decisions, existing industries and infrastructures, natural resources, established practices and so on' (Diji, 2019; Markard, 2018). This means that coal phase-out is likely to encounter quite different systemic issues peculiar to its environment.

Existing studies on energy transition, however, provide limited guidance on how to identify the systemic impediments for coal phase-out. This is because most of these studies has tended to focus on the emergence and diffusion of niche technologies (Markard, 2018). Relatively few studies have focused on the decline of incumbent technologies (see, for example, Lamberg et al., 2018; Turnheim and Geels, 2012). Of these, most have focused on the decline of a specific incumbent technology (for example, coal) with limited recognition of multi-technology interaction (for example, interaction between gas and coal) (Sanden and Hillman, 2011). As a result, no blueprint has emerged from the existing studies that can provide sound guidance for identifying impediments for coal phase-out (Gunningham, 2011; Markard, 2018). Accordingly, this paper seeks to explore systemic issues that may impede the phase-out of coal in the Greater Bay Region through empirical and context-specific research.

\subsection{Method}

An interview-based approach, widely used in the social sciences, is employed in this paper, for exploring the systemic impediments for coal phase-out in the Greater Bay Region. The appropriateness of this approach is justified in its ability to provide an in-depth, discursive forum for exploratory research (Lee et al., 2019; Mah, 2019). The use of this approach is also based on consideration that it has been successfully applied in the literature to analyse various 
energy policy issues including, for example, deployment of carbon capture and storage (CCS) technologies (Jones et al., 2017; Wallquist et al., 2009), energy governance with multiobjectives (Holley and Lecavalier, 2017), and social acceptance of infrastructure project (Jami and Walsh, 2017; Ngar-yin Mah, 2019).

In this study, unstructured interviews were conducted where rather than confining the conversation to a set of pre-defined questions, the participants were asked to share their opinions on the barriers for phasing out the use of coal in the Greater Bay Region. This type of interview was selected for its ability to facilitate a flexible two-way conversation between interviewer and participants and enabling participants to shape the content and subjects of the conversation (Longhurst, 2009; Wilson, 2014). As demonstrated by various studies, such interviews provide more in-depth and additional information regarding the topic under examination (King, 2004; Marshall and Rossman, 2006; Roder, 2016). This type of interview was also conducted based on the consideration that existing literature, as discussed in the previous section, provides limited guidance on how to identify the systemic impediments for coal phase-out. As a result, the interviews were mainly conducted to explore issues that affect coal phase-out in the Greater Bay Region, rather than to delineate the significance of a set of issues selected in advance based on some theories.

For analysing data and information collected from the interviews, this paper adopts content analysis which is widely used in the literature for analysing qualitative data (McTavish and Pirro, 1990). According to Hsieh and Shannon (2005), three approaches exist in the literature for conducting content analysis, namely, conventional, directed, and summative. In the conventional approach to content analysis, researchers ask participants open-ended questions, and make inferences from their answers based on his/her own analysis. In contrast, in the directed approach to content analysis, the questions for participants are designed based on preexisting theories, to validate or extend conceptually these theories. The summative content analysis focuses on identifying and quantifying certain words or content in text with the aim of understanding their contextual use (Hsieh and Shannon, 2005).

The conventional approach for content analysis is adopted in this paper. This is premised on the argument that this approach could enable the collection of direct information from participants without imposing preconceived theories. This argument is reasonable because no theory, as discussed in the previous section, exists in the literature that can provide sound guidance for identifying the systemic impediments for coal phase-out. As a result, rather than validating or refining a pre-existing theory, the conventional approach as applied in this paper 
is to explore issues that may arise during coal phase-out in the industry and power sectors, where almost all of the coal is consumed in the region. These issues may arise if coal phaseout compromises or hampers the overall performance of the energy system. This may be due to a complementary element (for example, renewable energy) in the system either missing, costly or of insufficient quality or quantity (Markard and Hoffmann, 2016), caused by, for example, lack of technical knowledge in developing alternative energy sources (Ghorashi and Rahimi, 2011), insufficient infrastructure for the delivery of these sources (Olaya and Dyner, 2017), and unfavourable market conditions for their uptake (van Ruijven and van Vuuren, 2009). In addition, these issues may also arise from concern about the flow-on impacts of coal phase-out on the larger socio-economic system. For example, the closure of local coal-fired power plants may make the region reliant on imports for satisfying its energy needs, leading to concern about the security of energy supply and its crippling effect on local development (Heinrichs and Markewitz, 2015).

It is worth noting that the interview-based analysis conducted in the paper is qualitative in nature, focused on examining the perceptions held by key energy stakeholders regarding the impediments for coal phase-out in the Greater Bay Region. This examination is important because the perceptions of key energy stakeholders have important and direct influence in shaping the decision-making of their respective organisations. It is from these perceptions of phasing out coal in the region, that stakeholders draw on to inform their decision-making, though these perceptions may themselves be informed by a range of factors including insights gained from quantitative analysis of the cost and feasibility of alternative energy sources for replacing coal in the energy mix, and others.

Furthermore, in order to enhance the validity of the analysis conducted in this paper, data and information obtained from the interviews were also compared and linked with the secondary data collected from a review of publicly available documents (Lee et al., 2019; Mah, 2019). The documents reviewed include government reports and policy documents, planning reports and media releases of energy and utility companies, reports of industry associations, peerreviewed journal articles, and media materials (such as magazines and newspapers). 
Table 2: Key organisations participated in the interviews

\begin{tabular}{|c|c|c|}
\hline $\begin{array}{c}\text { Date of } \\
\text { consultation }\end{array}$ & $\begin{array}{l}\text { Type of the } \\
\text { organisations }\end{array}$ & Name of the organisations \\
\hline 18 March & Think tank & Guangdong Electric Power Design Institute \\
\hline 18 March & Industry association & Guangdong Coal Transportation and Distribution Association \\
\hline 19 March & Industry association & Guangdong Oil \& Gas Association \\
\hline 19 March & Industry association & Guangdong Petroleum and Chemical Industry Association \\
\hline $21 \mathrm{March}$ & Public agency & Zhongshan Reform and Development Bureau \\
\hline 03 April & Energy company & Shenzhen Energy Group \\
\hline 03 April & Utility & China General Nuclear Power Corporation \\
\hline 03 April & Energy company & Shenzhen Qianhai Energy Investment and Development Ltd \\
\hline 18 April & Think tank & Policy Research Office of Shenzhen Government \\
\hline 18 April & Energy company & Guangdong Dapeng LNG Ltd \\
\hline 19 April & Public agency & Shenzhen Reform and Development Bureau \\
\hline 19 April & Think tank & China Development Institute \\
\hline 28 April & Public agency & Foshan Reform and Development Bureau \\
\hline 28 April & Public agency & Zhaoqing Reform and Development Bureau \\
\hline 06 May & Think tank & School of Energy and Environment, City University of Hong Kong \\
\hline 06 May & Energy company & The Hong Kong and China Gas Company \\
\hline 07 May & Think tank & Hong Kong Baptist University \\
\hline 09 May & Utility & Hong Kong Electric Company \\
\hline 09 May & Utility & China Light \& Power Company \\
\hline 10 May & Public agency & Hong Kong Electrical and Mechanical Services Department \\
\hline 16 May & Public agency & Huizhou Energy and Key Project Bureau \\
\hline 17 May & Public agency & Jiangmen Reform and Development Bureau \\
\hline 21 May & Energy company & Zhuhai Jinwan LNG Ltd \\
\hline 21 May & Public agency & Zhuhai Reform and Development Bureau \\
\hline 27 May & Energy company & State Power Investment Ltd \\
\hline 28 May & Public agency & Office of Energy Development of Macao \\
\hline 28 May & Public agency & Marine and Water Bureau of Macao \\
\hline 30 May & Public agency & Environmental Protection Agency of Macao \\
\hline 31 May & Utility & The Macao Electric Lighting Company \\
\hline
\end{tabular}




\section{Main results: Systemic impediments for coal phase-out}

The analysis of interview responses highlighted a set of key issues that reflect the systemic impediments to coal phaseout in both industry and power sectors as raised by interview participants. Figure 1 presents a summarised overview of these issues and supportive literature with details discussed below.

\subsection{Industry sector}

As indicated by several government officials involved in the interviews, significant efforts have been made by local governments in the Greater Bay Region over the past few years to push for coal-to-gas switching in industrial facilities. This is because many smaller-scale boilers, used in ceramic, textile, garment and papermaking industries of their respective jurisdictions, are not equipped with advanced pollution controls and produce large amounts of air pollution. Reducing their use could therefore help make the region's skies blue again.

However, interviewees from Foshan, Jiangmen, Zhongshan and Zhaoqing raised concern about the economic impact of coal-to-gas switching on their 'old', energy- and pollution-intensive industries (such as, ceramic industry). One interviewee noted that 'local industries are reluctant to switch to gas because this is likely to increase their cost of production and adversely affect their economic competitiveness'. Another interviewee further elaborated on this point: 'the gas price is about three times of the coal price, and large investment is also required for facility upgrading if switching to gas for production...these could substantially increase the cost of production in local industry...the subsidies provided by local government are insufficient even for covering one-year of operating costs'. This view gets substantiated by the fact that the region's city-gate gas price is about RMB 2.06/C.M., which is one of the highest in the country (NDRC, 2018). This high price is translated into high end-user prices (RMB 3.50/C.M., or $\$ 15 / \mathrm{mmBtu}$ ), as compared with other provinces (less than RMB 2.75/C.M., or \$12/mmBtu) with similar gas demand (O'Sullivan, 2019).

Interviewees also pointed to the lack of access to gas infrastructure (supply) as a key barrier for coal-to-gas switching in industry. For instance, as noted by one interviewee, most of the ceramic companies in Jiangmen are in areas with no transmission pipeline interconnection. Interviewees also noted similar situations in Zhaoqing and Huizhou. Participants from Guangdong Oil \& Gas Association (the top regional body representing gas and petroleum businesses) argued that the 'lengthy approval process' is in part to blame for the problem of gas accessibility, as the 'approval time for a gas project is 5 years on paper, but usually takes up to 10 years, requiring more than 100 approval stamps'. 
Figure 1: Issues of coal phase-out and supportive literature

\section{Issues of coal phase-out}

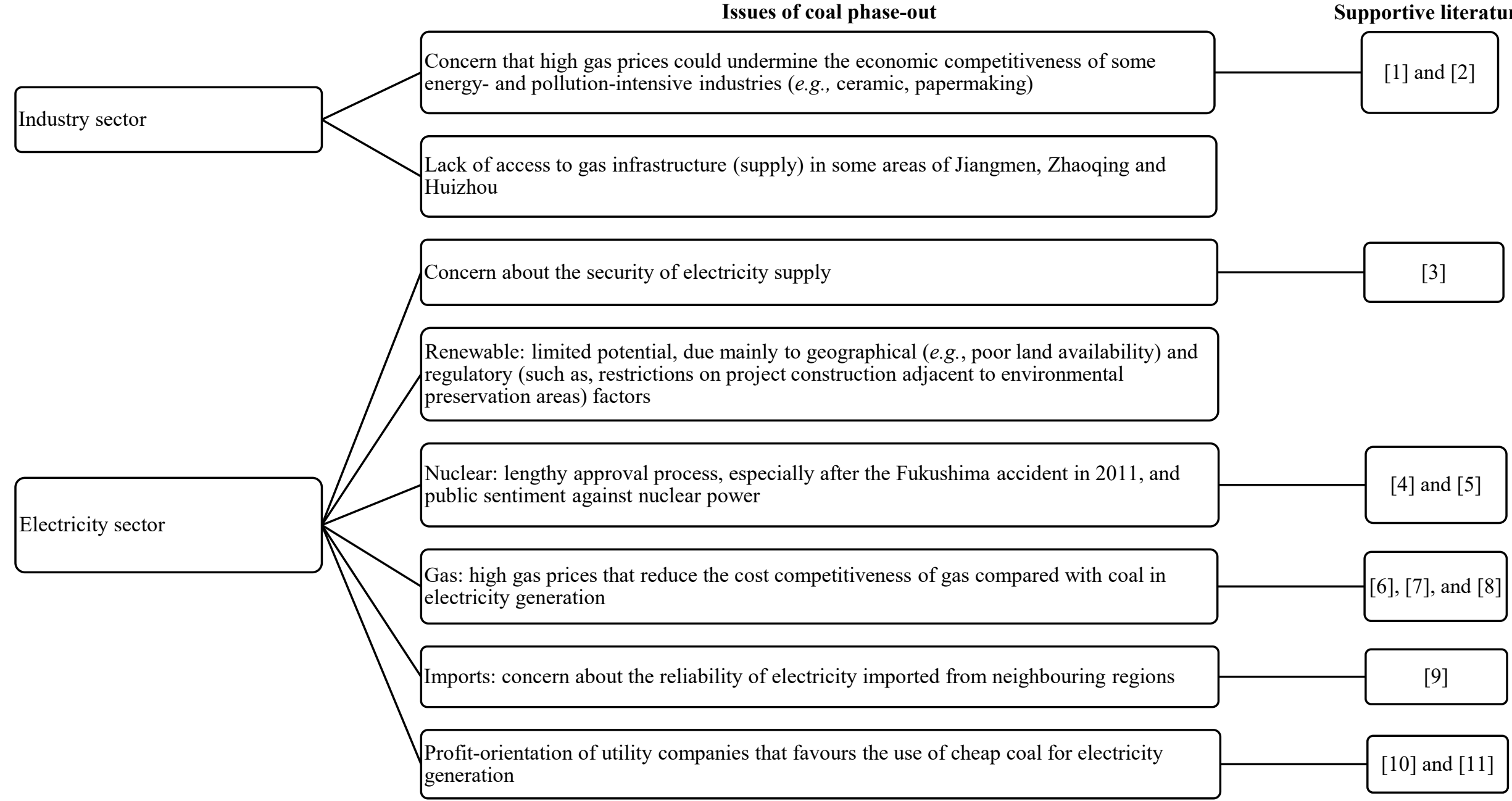

Notes: [1] NDRC (2018); [2] O'Sullivan (2019); [3] He and Yang (2011); [4] MEE (2019); [5] WNA (2020); [6] HK Government (2019); [7] Lin et al. (2019); [8] Pollitt et al. (2017); [9] Liu et al. (2018); [10] Luo et al. (2019); [11] Liu and Jin (2020). 


\subsection{Power sector}

During the interviews, almost all participants expressed concern that the closure of local coalfired power units may pose challenges with respect to energy security. For example, as suggested by one interviewee representing a utility company, 'it may be worth considering keeping some local coal-fired capacity as a backup to ensure the security of supply in the situations when major transmission failures happen due to typhoon or other extreme weather events'. A similar view was echoed by another interviewee that 'about $75 \%$ of the electricity consumed in Foshan is currently imported... it is very necessary to improve the energy selfsufficiency of the city to ensure uninterrupted electricity supply, especially for household consumers and key enterprises'. An official from the Office of Energy Development of Macao also suggested that 'the issue of energy security is very important, and local generation capacity must be increased to ensure the security of electricity supply, especially for some key departments, such as hospitals'.

This concern about energy security is understandable if one notes that about half of the electricity consumed in the region is from imports. In such context, local coal-fired capacity plays an important role in ensuring the security of supply, especially during extreme weather conditions. In fact, the region is among the most vulnerable of the country's coastal areas to extreme weather events (such as, typhoons, cyclones and intense rains), which cause serious damage to electric power infrastructure (He and Yang, 2011).

As indicated by some interviewees, the lack of alternative local supply options, together with energy security concern, pose the biggest challenges to the phase-out of coal in the power sector. Firstly, in the most populous cities of the region (Hong Kong, Shenzhen, Guangzhou and Macao), high population density and limited land availability preclude the deployment of largescale renewable projects. One interviewee representing the Office of Energy Development of Macao noted that 'because of the scarcity of land resources in Macao, large-scale wind and solar power generation is not advisable'. In less populous cities (for example, Zhaoqing, Huizhou and Zhuhai), some interviewees noted that although some wind projects were planned, they were difficult to pass through the environmental assessment, because they were in areas adjacent to the 'ecologically functional zones'. Moreover, roof-top solar PV was noted by interviewees as having regulatory challenges, because the ownership rights of rooftop in commercial buildings and residential apartments would have to be clarified or amended to account for this new phenomenon. 
Secondly, ensuring energy security by increasing nuclear capacity was regarded by a few interviewees as infeasible, especially in the short-term, due mainly to the prolonged approval process. One interviewee from Guangdong Oil \& Gas Association noted that 'it is still difficult for nuclear to replace coal in the region because of the difficulty of obtaining approval'. This view was confirmed by one official from Jiangmen that 'satisfying the projected growth of electricity demand requires the planned four nuclear generating units to be completed...there is currently no timeline for when they will become available...after the Fukushima nuclear accident, rising anti-nuclear sentiment makes the approval difficult to obtain'.

The difficulty for nuclear development gets substantiated if one notes that immediately after the Fukushima accident in 2011, the State Council suspended approvals for new nuclear projects and introduced more stringent safety checks for existing projects (including those under construction) (WNA, 2020). Until now, no consensus seems to have been reached on the future of nuclear power in China, as indicated by a broad range of projected capacity figures for 2050 , from $150 \mathrm{GW}$ to $500 \mathrm{GW}$, published by government agencies and research institutes (Hibbs, 2018). As of 2019, only one proposed nuclear project (i.e., Taipingling units 1 and 2) with capacity of 2,300 MW is under construction (MEE, 2019). Others are still waiting for the construction permits (WNA, 2020). Nuclear power is therefore unlikely to play a bigger role in ensuring the security of electricity supply in the near future.

Thirdly, high gas prices were frequently mentioned by participants during the interviews as disincentivising the use of gas capacity. For example, in Hong Kong, electricity prices are regulated by the Scheme of Control Agreement between two electric utilities (namely, CLP Power and HK Electric) and the Hong Kong SAR government, based on cost-plus principle, where utilities are allowed to charge prices that could cover their supply costs including a reasonable return (8\%) on investments (HK Government, 2019). Under these arrangements, utility companies will have to increase the electricity prices for their customers if they want to cover the cost increase arising from high gas prices. This would however affect the affordability of electricity in the city. Participants from Hong Kong utility companies went on to argue that: 'Hong Kong has one of the most affordable electricity in the world, and the residents of the city are very sensitive to tariff increase...but the profitability of utility companies will be affected if high gas price is not reflected in electricity prices'.

In the cities of Guangdong province, wholesale competition has been introduced in the electricity market since 2015, where large consumers are enabled to purchase electricity directly from the market or indirectly from competitive retailers (Lin et al., 2019). For other 
consumers, electricity prices remain fixed and continue to be determined by regulation (Pollitt et al., 2017). This means that high gas prices are not reflected in electricity prices for noncompetitive consumers, hence discouraging the use of gas capacity. Interviewees from local utility companies who operate gas-fired cogeneration units in Guangzhou and Dongguan confirmed this view. As noted by one interviewee, 'at present, the main problem restricting the replacement of coal with gas for power generation is the high gas price'.

Several participants from municipal governments also noted that market reform has tended to encourage the use of coal in power generation, because coal-fired power units are in general cost-competitive as compared with other types of power units. One interviewee noted that 'Zhuhai's coal-fired power plants are highly efficient and low-cost...the introduction of wholesale electricity trading has encouraged more generation from these plants...the municipal government lacks effective policy instrument to control coal generation in the market, and this makes the coal consumption control target difficult to attain'. This may seem surprising if one notes that Guangdong started its Emission Trading Scheme (ETS) in 2013, which is likely to improve the cost-competitiveness of gas and renewable generation by increasing the cost of coal generation. But a closer assessment of the region's experience with ETS, as presented in Luo et al. (2019), suggests that the ETS has only slightly increased the cost of fossil-fuels generation by $0.5 \%$, and hence has limited influence on encouraging the use of less carbonintensive technologies in power generation. Similarly, Liu and Jin (2020) found that the carbon price had limited impact on increasing the cost of coal generation, and some large-scale and efficient coal-fired power plants even made profits, due mainly to generous emission allowance allocation.

A few interviewees from Hong Kong were also sceptical about the option of electricity imports from Mainland China. One argument that they have taken is that the city's reliability of electricity supply is one of the highest in the world at the rate of $99.999 \%$ in the most recent years, which is equivalent to less than 1 minute of supply interruption per consumer in a year. The reliability of electricity supply in the southern grid cannot meet such a high level of reliability. Apart from the reliability issue, some interviewees also highlighted that there has been concern about supply interruption from Mainland China, and this concern has become more acute in the past few years. Likewise, one interviewee from Mainland China also raised concern about the reliability of imports from neighbouring provinces by referring to recent hydropower curtailment in Yunnan province. According to Liu et al. (2018), the main factors responsible for this hydropower curtailment were a lack of interconnection capacity, 
insufficient reservoir storage capacity, prolonged project approval process, and inflexible mechanisms for cross-regional electricity trading.

\section{Discussion}

The Greater Bay Region is a resource-poor region, endowed with limited indigenous energy sources, both renewable and non-renewable. In such context, coal has historically played an important role in ensuring cheap and reliable energy supply in the region, and its phase-out would inevitably lead to concern about energy security (such as, affordability, availability), especially if alternative energy sources cannot be effectively deployed, due to a range of market (e.g., high gas price), infrastructure (such as, lack of gas infrastructure), and regulatory (e.g., prolonged project approval process) issues, as discussed in the previous section. Redressing these issues is therefore a key pre-requisite for facilitating a timely and orderly phase-out of coal in the region. This is however not an easy task, and cannot be accomplished if local governments work in isolation from each other, especially if one notes the limited and disperse nature of energy endowment in the region. Instead, it requires close-centre-local and inter- and intra-regional cooperation, which is likely to pose significant challenges arising from the longstanding nature of the energy policy process in China, most notably fragmented authority, and territorial administrative divisions.

\subsection{Fragmented authority}

It is widely agreed that deeper gas market reform is required in China to enable third-party access to gas networks and more cost-reflective gas pricing. These are expected to lower gas prices, especially for large industrial users and power generators, which would in turn encourage them to switch to less carbon-intensive gas for production (Cornot-Gandolphe, 2019; IEA, 2019b). In fact, as discussed in the previous section, the participants in the interviews identified high gas prices as a key barrier for coal-to-gas switching in the Greater Bay Region. In China, the design and implementation of gas market reform is a shared responsibility between a wide range of central and local ministries and state-owned enterprises (especially, the three national oil companies) (Ishwaran et al., 2017; Shi and Variam, 2015; Wang et al., 2020c). In addition, a variety of 'policy entrepreneurs' (NGOs, think tanks, etc.) also has important influence in shaping reform policies, enabled by various consultative and deliberative practices (Grunberg, 2017; He and Thogersen, 2010; Mertha, 2009). In such environment, policy decisions tend to be made based on consensus through extensive bargaining and consultation both horizontally between government agencies, state-owned enterprises, and private actors, as well as vertically across different levels of government 
(Andrew-Speed and Zhang, 2019). In this process, coordination is extremely challenging, especially when the actors involved have different views or the top leadership is divided over the issue (Cunningham, 2007; Xu and Yang, 2015). According to Andrew-Speed and Zhang (2019), this coordination challenge gets further compounded by: 1) the lack of formal definition of the scope of authority of public agencies and clear guidelines for structuring interorganisational relations; 2) high reliance on informal networks and personal connections for consensus-building; and 3) limited scope of bargaining, mainly confined to public agencies or officials of equal rank.

The coordination challenge has contributed to significant delays of the gas reform programs. For example, in 2014, the National Energy Administration (NEA) introduced the Regulatory Approach of Fair and Open Access to Oil and Gas Pipeline Facilities (Trial), which enables non-discriminatory third-party access to gas pipeline facilities - a key precondition for the establishment of the primacy of pricing mechanisms (NEA, 2014). In the same year, the National Development and Reform Commission (NDRC) issued the Order for the Construction and Operation Management of Natural Gas Infrastructure, which clearly stipulates the requirement for 'fair' third-party access to network infrastructure including pipelines and LNG terminals (NDRC, 2014). The implementation of the third-party access policy has however been slow, and mainly confined to a few trials conducted on LNG terminals. Most of the gas continues to be supplied by the three national oil companies that control virtually all gas production and network facilities (IEA, 2019b). Similarly, gas price reforms have been implemented in China since 2011, with a view to replace the regulated cost-plus pricing mechanisms with market-based mechanisms. Table 3 presents key gas price reform policies in China. The implementation of these policies has not led to the development of fullfledged market-based mechanisms for gas pricing, and significant price controls remain for most commercial and residential consumers, despite some progress of price deregulation on unconventional gas and LNG imports (O'Sullivan, 2019; Rioux et al., 2019; Wang et al., 2020c). 
Table 3: Gas pricing reforms in China: Key policies

\begin{tabular}{|c|c|c|}
\hline Time & Policy & Key point content \\
\hline $\begin{array}{c}\text { End of } \\
2011\end{array}$ & $\begin{array}{l}\text { Notice on Carrying Out Pilot } \\
\text { Reform of Natural Gas Pricing } \\
\text { Mechanism in Guangdong } \\
\text { Province and Guangxi Zhuang } \\
\text { Autonomous Region }\end{array}$ & $\begin{array}{l}\text { - Trials on 'netback' pricing mechanisms in Guangdong and } \\
\text { Guangxi provinces } \\
\text { - These mechanisms link gas prices with alternative energy } \\
\text { prices, and de-regulate the wellhead prices of unconventional } \\
\text { gases (such as, shale gas, coalbed gas, and coal-to-gas) }\end{array}$ \\
\hline July 2013 & $\begin{array}{l}\text { Notice on Adjustment of Natural } \\
\text { Gas Prices }\end{array}$ & $\begin{array}{l}\text { - Introduction of nationwide market-based gas pricing } \\
\text { mechanisms } \\
\text { - These mechanisms introduce two categories of gas (namely, } \\
\text { existing gas volumes and incremental gas volumes), and } \\
\text { link the prices of incremental gas with import prices of } \\
\text { alternative energy ( } 40 \% \text { of LPG and } 60 \% \text { of heavy fuel oil) }\end{array}$ \\
\hline April 2015 & $\begin{array}{l}\text { Notice on Rationalising the Price } \\
\text { of Non-residential Natural Gas }\end{array}$ & $\begin{array}{l}\text { - Reducing the benchmark price of the incremental gas } \\
\text { volume by CNY } 0.44 / \mathrm{m}^{3} \\
\text { - Increasing the price of the existing gas volume by CNY } \\
0.04 / \mathrm{m}^{3} \\
\text { - Price deregulation for directly supplied large industrial } \\
\text { consumers (except fertiliser gas) }\end{array}$ \\
\hline $\begin{array}{l}\text { November } \\
2015\end{array}$ & $\begin{array}{l}\text { Notice on Reducing the Station } \\
\text { Price of Non-residential Natural } \\
\text { Gas and Further Promoting the } \\
\text { Price Market Reform }\end{array}$ & $\begin{array}{l}\text { - Decreasing the benchmark price of the incremental gas } \\
\text { volume by CNY } 0.70 / \mathrm{m}^{3} \\
\text { - Introduction of a 'benchmark price + floating range' } \\
\text { mechanism, which allows gas price rise by up to } 20 \% \text { with } \\
\text { no price floor }\end{array}$ \\
\hline $\begin{array}{l}\text { October } \\
2016\end{array}$ & $\begin{array}{l}\text { Notice on Clarifying Pricing } \\
\text { Policies for Gas Storage Facilities }\end{array}$ & - Price deregulation for gas storage services \\
\hline $\begin{array}{l}\text { November } \\
2016\end{array}$ & $\begin{array}{l}\text { Notice on Promoting the Fertiliser } \\
\text { Gas Price Market Reform }\end{array}$ & - Price deregulation for fertiliser gas \\
\hline $\begin{array}{l}\text { November } \\
2016\end{array}$ & $\begin{array}{l}\text { Notice on Relevant Matters } \\
\text { Concerning the Natural Gas } \\
\text { Station Price Policies in Fujian }\end{array}$ & - Trials on city-gate gas price reform in Fujian province \\
\hline $\begin{array}{l}\text { September } \\
2017\end{array}$ & $\begin{array}{l}\text { Notice on Reducing the } \\
\text { Benchmark Station Price of Non- } \\
\text { residential Natural Gas }\end{array}$ & $\begin{array}{l}\text { - Decreasing the benchmark price of the incremental gas } \\
\text { volume for non-residential consumers by CNY } 0.1 / \mathrm{m}^{3} \\
\text { - Price deregulation for gas traded in the gas exchanging } \\
\text { centres }\end{array}$ \\
\hline May 2018 & $\begin{array}{l}\text { Notice on Rationalising } \\
\text { Residential Gas Station Prices }\end{array}$ & $\begin{array}{l}\text { - Gas price unification between residential and non- } \\
\text { residential consumers }\end{array}$ \\
\hline
\end{tabular}

Source: IEA (2019b); O'Sullivan (2018); Shi and Variam (2015); Wang et al. (2020c) 
The coordination challenge has also impeded the development of cross-regional network projects, which are considered as one of the key options for the Greater Bay Region to improve its energy security, because it can increase the region's import capacity from resource-rich western provinces (such as, Yunnan province). The authority to plan and approve major network projects was initially held by the NDRC, together with a few other central ministries such as, Ministry of Industry and Information Technology (MIIT), Ministry of Finance (MOF), and Ministry of Ecology and Environment (MEE). Some of this authority has gradually been relegated to provincial governments over the past few years in an effort to attract investment in large-scale projects and strengthen the role of provincial government in supervising projects during their construction phase (Chen et al., 2019). The significant conflicts of interest and lack of effective coordination among various public agencies across different levels of government have been identified by some studies as one of the key reasons for the slower-than-expected progress of several large ultra-high voltage direct current (UHVDC) transmission projects (Cui et al., 2020; Li, 2014; Liu et al., 2018; Su, 2019), which form the backbone of the southern corridor of the West-East Electricity Transfer Project, aimed at exporting hydropower from Yunnan to Guangdong (Liu et al., 2019).

\subsection{Territorial administrative divisions}

The Mainland China is governed by a top-down, hierarchical administrative system inherited from the socialist era (Xu and Yeh, 2013). In this system, the central government has exerted top-down control over the appointment and promotion of lower levels officials (Huang, 1996). Meanwhile, much of the decision-making power has been gradually delegated to local governments (such as, provincial, and municipal), which are responsible for policy implementation and regulation enforcement within their respective localities (Heberer and Gunter, 2012; Xu, 2011). The central control over local officials' careers, together with local responsibility for policy implementation, have created strong incentives for local governments to pursue 'administrative territory-based interests' ( $\mathrm{Li}$ and $\mathrm{Wu}, 2018$ ). These incentives get further strengthened by the lack of mechanisms for forging horizontal cooperation, as government relations are often articulated through top-down administrative measures (Wang et al., 2020a; Xu and Yeh, 2011). Similarly, Hong Kong and Macao are governed by a system of 'one country, two systems', in which they are given a high degree of autonomy in making their own policy decisions, except in the areas of foreign affairs and defence (Wong and Xiao, 2018). 
The territorial administrative divisions have provided powerful impetus to economic growth, as different localities have been able to pursue developmental strategies that suit their local conditions (Zhong, 2015). They have however also made intra-regional cooperation difficult because local governments tend to consider their own interests when making decisions regarding the energy sector (van Rooij et al., 2017; Wang et al., 2020a; Yang and Jin, 2011). For example, $25 \%$ of Hong Kong's electricity needs is imported from Guangdong Daya Bay nuclear power plant, through a dedicated transmission line for point-to-point supply. A proposal has been made by Guangdong to upgrade it to a grid-to-grid supply, based on the argument that this could enable better dispatch scheduling and improved nuclear safety, because it is difficult for the nuclear power plant to adjust its output on short notice. But the Hong Kong electric utility (CLP Power) has shown little interest in the proposal, due mainly to technical (e.g., different technical standards between mainland China and Hong Kong electric grids) and financial (for example, large investment required to accommodate this difference) considerations. Besides, the significant duplication of infrastructure facilities (e.g., five international airports in the region competing with each other) may also lend some credence to the lack of cooperation across the Greater Bay Region, despite some efforts made on promoting regional cooperation on infrastructure development since 2002 (Cheung, 2012).

\section{Conclusions and policy implications}

By using the Greater Bay Region as a case study, this paper developed an analysis of impediments for coal phase-out. The results of the analysis suggest that coal phase-out in the region has encountered a range of market (e.g., high gas price), infrastructure (such as, lack of gas infrastructure), and regulatory (e.g., prolonged project approval process) issues, which have impeded the deployment of alternative energy sources, raising serious concern about coal phase-out and its crippling impacts on the security of energy supply (e.g., affordability, and availability). Redressing these issues is therefore a key policy priority for promoting an orderly and timely phase-out of coal in the region. This would require a mix of policies addressing two dimensions: 1) those aimed at squeezing out coal from the energy-mix that is considered as essential for creating 'windows of opportunity' for the uptake of alternative low-carbon energy sources, and 2) those aimed at supporting the uptake of these low-carbon energy sources and building elements required for such to thrive.

However, the design and implementation of these policies will pose significant challenges, especially to a resource-poor region, like the Greater Bay Region, because it cannot be achieved if local governments work in isolation with each other, given the limited and disperse nature 
of regional energy endowment. Instead, it would require close-centre-local, and inter- and intraregional cooperation, which would be impeded by the fragmented authority and territorial administrative divisions that have long characterised the energy policy process of China. This issue has already been recognised by the Chinese government, and a Central Leading Group chaired by the Vice Premier Han Zheng has recently been created to promote cooperation on the development of the Greater Bay Region. The Central Leading Group is a special institutional arrangement in China for promoting closer coordination across the boundaries of state institutional structures in redressing strategically important and complex policy issues (Chen et al., 2019).

We suggest that the capacity of the Central Leading Group can be further strengthened if an energy task force, with membership from all energy-related central and local public agencies and companies, can be established as part of it. The task force can act as a strategic entry point for various energy stakeholders to elevate the status of energy cooperation in the regional policy settings. This is critical especially if one notes that energy has only occasionally risen to the top of the central policy agenda in China, even though it has always been a policy concern due to its important role in promoting social wellbeing and economic prosperity (AndrewSpeed and Zhang, 2019). The elevation of energy cooperation in the regional policy settings would require a cogent plan for cooperative energy development. The energy task force should be responsible for developing this plan, commensurate with the regional developmental priorities stipulated in the Outline Development Plan for the Guangdong-Hong Kong-Macao Greater Bay Area. The development of such a plan should also be based on a comprehensive appraisal - through the application of formal modelling and analytical techniques - of technical and socio-economic impacts of alternative future scenarios (low-carbon transition pathways) for meeting the energy needs of the region in a sustainable and affordable manner. In addition, the task force should also be empowered to periodically (e.g., every five years) review the energy plan, and advice the Central Leading Group on the need for revisiting specific elements of it.

\section{Acknowledgement}

This work was supported by the National Natural Science Foundation of China (No. 71603248), and Science and Technology Planning Project of Guangdong Province (No. 2017A050501060). 


\section{References}

Aklin, M., Urpelainen, J., 2013. Political competition, path dependence, and the strategy of sustainable energy transitions. American Journal of Political Science 57, 643-658.

Andrew-Speed, P., Zhang, S., 2019. China as a global clean energy champion. Palgrave Macmillan, Singapore.

Avelino, F., Grin, J., 2017. Beyond deconstruction: A reconstructive perspective on sustainability transition governance. Environmental Innovation and Societal Transitions 22, $15-25$.

Bakker, S., 2014. Actor rationales in sustainability transitions - Interests and expectations regarding electric vehicle recharging. Environmental Innovation and Societal Transitions 13, 60-74.

Bohnsack, R., Pinkse, J., Waelpoel, A., 2016. The institutional evolution process of the global solar industry: The role of public and private actors in creating institutional shifts. Environmental Innovation and Societal Transitions 20, 16-32.

Boons, F., Ludeke-Freund, F., 2013. Business models for sustainable innovation: State-of-theart and steps towards a research agenda. Journal of Cleaner Production 45, 9-19.

Chen, D., Mollet, P., Brian, E., 2019. Energy governance in China: The structures and processes of government decision-making The King Abdullah Petroleum Studies and Research Center (KAPSARC), Saudi Arabia.

Cheung, P.T.-Y., 2012. The role of government in managing cross-boundary co-operation between Hong Kong and mainland China, in: Chiu, W.-K., Wong, S.-L. (Eds.), Repositioning the Hong Kong Government: Social Foundations and Political Challenges. Hong Kong University Press, Hong Kong, pp. 187-218.

Cornot-Gandolphe, S., 2019. China's quest for blue skies: The astonishing transformation of the domestic gas market. Institut francaus des relations (ifri), France.

Cui, Q., He, L., Han, G., Chen, H., Cao, J., 2020. Review on climate and water resource implications of reducing renewable power curtailment in China: A nexus perspective. Applied Energy 267, 115114.

Cunningham, E.A., 2007. China's energy governance: Perception and reaity. MIT Center for International Studies, United States.

Diji, C.J., 2019. Energy transition process and sustainable development, in: Filho, W.L. (Ed.), Encyclopedia of Sustainability in Higher Education. Springer, Switzerland, pp. 516-523.

Dijk, M., Well, P., Kemp, R., 2016. Will the momentum of the electric car last? Testing an hypothesis on disruptive innovation. Technological Forecasting \& Social Change 105, 77-88.

Elias, S.A., 2018. Climate Change and Energy. Encyclopedia of the Anthropocene 1, 457-466.

Environment Bureau, 2017. Hong Kong's Climate Action Plan 2030+. The Government of the Hong Kong Special Administrative Region, Hong Kong.

EPD, 2014. Co-operation agreement on regional air pollution control and prevention comes into effect and Macau joints the regional air quality monitoring network. Environmental Protection Department of Hong Kong, Hong Kong.

Fei, T., 2018. Coal transition in China: Options to move from coal cap to managed decline under an early emissions peaking scenario. IDDRI and Climate Strategies, United Kingdom. 
Feng, Y., Ning, M., Lei, Y., Sun, Y., Liu, W., Wang, J., 2019. Defending blut sky in China: Effectiveness of the 'Air Pollution Prevention and Control Action Plan' on air quality improvements from 2013 to 2017. Journal of Environmental Management 252, 109603.

Gass, P., Echeverria, D., 2017. Fossil fuel subsidy reform and the just transition. International Institute for Sustainable Development, Canada.

Geels, F.W., 2011. The multi-level perspective on sustainability transitions: Responses to seven criticisms. Environmental Innovation and Societal Transitions 1, 24-40.

Geels, F.W., 2014. Reconceptualising the co-evolution of firms-in-industries and their environments: Developing an inter-disciplinary Triple Embeddedness Framework. Research Policy 43, 261-277.

Geels, F.W., Schot, J., 2007. Typology of sociotechnical transition pathways. Research Policy $36,399-417$.

Ghorashi, A.H., Rahimi, A., 2011. Renewable and non-renewable energy status in Iran: Art of know-how and technology-gaps. Renewable and Sustainable Energy Reviews 15, 729-736.

Grunberg, N., 2017. Revisiting fragmented authoritarianism in China's central energy administration, in: Brodsgaard, K.E. (Ed.), Chinese politics as fragmented authoritarianism: Earthquakes, energy and environment. Routledge, London and New York, pp. 15-37.

Guangdong Bureau of Statistics, 2019. Guangdong Statistical Yearbook, Guangdong.

Gunningham, N., 2011. Energy governance in Asia: beyond the market. East Asia Forum 3, 29-30.

Hansen, M.H., Li, H., Svarverud, R., 2018. Ecological civilisation: Interpreting the Chinese past, projecting the global future. Global Environmental Change 53, 195-203.

He, B., Thogersen, S., 2010. Giving the people a voice? Experiments with consultative authoritarian institutions in China. Journal of Contemporary China 19, 675-692.

He, C., Yang, L., 2011. Urban development of climate change in China's Pearl River Delta. Lincoln Institute of Land Policy, United States.

Heberer, T., Gunter, S., 2012. County and township cadres as a strategic group. A new approach to political agency in China's local state. Journal of Chinese Political Science 17, 221 249.

Heinrichs, H.U., Markewitz, P., 2015. A coal phase-out in Germany - Clean, effiient and affordable? . Energy Procedia 75, 2541-2547.

Henderson, R., Newell, R.G., 2010. Accelerating energy innovation: Insights from multiple sectors. National Bureau of Economic Research, Cambridge.

Hess, D.J., 2016. The politics of niche-regime conflicts: Distributed solar energy in the United States. Environmental Innovation and Societal Transitions 19, 42-50.

Hibbs, M., 2018. The future of nuclear power in China. Carnegie Endowment for International Peace, United States.

HK Government, 2019. Scheme of control agreement. Hong Kong SAR Government, Hong Kong.

Holley, C., Lecavalier, E., 2017. Energy governance, energy security and environmental sustainability: A case study from Hong Kong. Energy Policy 108, 379-389. 
Hsieh, H.-F., Shannon, S.E., 2005. Three approaches to qualitative content analysis. Qualitative Health Research 15, 1277-1288.

Huang, Y., 1996. Inflation and investment controls in China: The political economy of centrallocal relations during the reform era. Cambrideg University Press, Cambridge.

Hudson, M., 2019. Enacted inertia: Australian fossil fuel incumbents' strategies to undermine challengers, in: Wood, G., Baker, K. (Eds.), The Palgrave Handbook of Managing Fossil Fuels and Energy Transitions. Palgrave Macmillan, Switzerland, pp. 195-222.

IEA, 2019a. CO2 emissions from fuel combustion. International Energy Agency, Paris.

IEA, 2019b. Gas market liberalisation reform: Key insights from international experiences and the implications for China. International Energy Agency, Paris.

IEA, 2019c. World Energy Investment. International Energy Agency, Paris.

IEA, 2019d. World Energy Outlook 2019. International Energy Agency, Paris

Ishwaran, M., King, W., Haigh, M., Lee, T., Nie, S., 2017. China's current natural gas market mechanisms and regulatory system, in: Swennen, R., Leuven, K.U. (Eds.), China's Gas Development Strategies. Spinger, United Kingdom, pp. 261-285.

Jami, A.A., Walsh, P.R., 2017. From consultation to collaboration: A participatory framework for positive community engagement with wind energy projects in Ontario, Canada. Energy Research and Social Science 27, 14-24.

Jones, C.R., Olfe-Krautlein, B., Kaklamanou, D., 2017. Lay perceptions of carbon dioxide utilisation technologies in the United Kingdom and Germany: An exploratory qualitative interview study. Energy Research and Social Science 34, 283-293.

Kemp, R., Rip, A., Schot, J., 2001. Constructing transition paths through the management of niches, in: Garud, R., Karnoe, P. (Eds.), Path dependence and creation. Lawrence Erlbaum Associates, London, pp. 269-299.

Kern, F., Rogge, K.S., 2016. The pace of governed energy transitions: Agency, international dynamics and the global Paris agreement accelerating decarbonisation processes. Energy Research and Social Science 22, 13-17.

Kern, F., Rogge, K.S., 2018. Harnessing theories of the policy process for analysing the politics of sustainability transitions: A critical survey. Environmental Innovation and Societal Transitions 27, 102-117.

King, N., 2004. Using interviews in qualitative research, in: Cassell, C., Symon, G. (Eds.), Essential guide to qualitative methods in organisational research. Sage, London, pp. 11-22.

Klitkou, A., Bolwig, S., Hansen, T., Wessberg, N., 2015. The role of lock-in mechanisms in transition processes: The case of energy for road transport. Environmental Innovation and Societal Transitions 16, 22-37.

KPMG, 2019. Greater Bay Area Update: Outline Development Plan for the Guangdong-Hong Kong-Macao Greater Bay Area. KPMG, Hong Kong.

LaBelle, M., Horwich, M., 2017. The breakthout if energy innovation, in: Goldthau, A. (Ed.), The Handbook of Global Energy Production. Wiley-Blackwell, Oxford.

Lamberg, J.-A., Ojala, J., Peltoniemi, M., 2018. Thinking about industry decline: A qualitative meta-analysis and future research directions. Business History 60, 127-156. 
Lauber, V., Jacobsson, S., 2016. The politics and economics of constructing, contesting and restricting socio-political space for renewables - The German Renewable Energy Act. Environmental Innovation and Societal Transitions 18, 147-163.

Lee, H., Jung, E.-Y., Lee, J.-D., 2019. Public-private co-evolution and niche development by technology transfer: A case study of state-led electricity system transition in South Korea. Energy Research and Social Science 49, 10-113.

Li, Q., 2014. 'Direct power purchase' or 'West to East' 21st Century Business Herald, China.

Li, Y., Wu, F., 2018. Understanding city-regionalism in China: regional cooperation in the Yangtze River Delta. Regional Studies 52, 313-324.

Lin, J., Kahrl, F., Yuan, J., Chen, Q., Liu, X., 2019. Economic and carbon emission impacts of electricity market transition in China: A case study of Guangdong Province. Applied Energy 28, 1093-1107.

Liu, B., Liao, S., Cheng, C., Chen, F., Li, W., 2018. Hydropower curtailment in Yunnan Province, southwestern China: Constraint analysis of suggestions. Renewable Energy 121, 700-711.

Liu, S., Yang, Q., Cai, H., Yan, M., Zhang, M., Wu, D., Xie, M., 2019. Market reform of Yunnan electricity in southwestern China: Practice, challenges and implications. Renewable and Sustainable Energy Reviews 113, 109265.

Liu, X., Jin, Z., 2020. An analysis of the interactions between electricity, fossil fuel and carbon market prices in Guangdong, China. Energy for Sustainable Development 55, 82-94.

Lockwood, M., Kuzemko, C., Mitchell, C., Hoggett, R., 2016. Historical institutionalism and the politics of sustainable energy transitions: A research agenda. Environment and Planning C: Politics and Space 5, 312-333.

Longhurst, R., 2009. Interviews: In-depth, semi-structured. International Encyclopedia of Human Geography, 580-584.

Loorbach, D., van Bakel, J.C., Whiteman, G., Rotmans, J., 2010. Business strategies for transitions towards sustainable systems. Business SStrategy and the Environment 19, 133-146.

Luo, Y., Wang, W., Li, X., Zhao, D., 2019. The Guangdong Emissions Trading Scheme. Strategic Planning for Energy and the Environment 8, 42-62.

Ma, T., 2017. China's ambitious new clean energy targets, The Diplomat. James Pach, United States.

Mah, D.N.-y., 2019. Community solar energy initiatives in urban energy transitions: A comparative study of Foshan, China and Seoul, South Korea. Energy Research and Social Science 50, 129-142.

Markard, J., 2018. The next phase of the energy transition and its implications for research and policy. Nature Energy 3, 628-633.

Markard, J., Hoffmann, V.H., 2016. Analysis of complementarities: Framework and examples from the energy transition. Technological Forecasting \& Social Change 111, 63-75.

Markard, J., Suter, M., Ingold, K., 2016. Socio-technical transitions and policy change: Advocacy coalition in Swiss energy policy. Environmental Innovation and Societal Transitions $18,215-237$.

Marshall, C., Rossman, G.B., 2006. Designing qualitative research. Sage, London. 
McTavish, D.G., Pirro, E.B., 1990. Contextual content analysis. Quality and Quantity 24, 245265.

MEE, 2019. Notice on Issuing the Construction Permits for Guangdong Taipingling Nuclear Power Plant Units 1 and 2. Ministry of Ecology and Environment of the People's Republic of China, China.

Mertha, A., 2009. Fragmented authoritarianism 2.0: Political pluralisation in the Chinese policy process. The China Quarterly 200, 995-1012.

Mirae Asset, 2020. Guangdong to close coal power plants. Mirae Asset Global Investments, Hong Kong.

Moriarty, P., Honnery, D., 2012. What is the global potential for renewable energy? . Renewable and Sustainable Energy Reviews 16, 244-252.

Myllyvirta, L., Zhang, S., Shen, X., 2020. Will China build hundreds of new coal plants in the 2020s. Carbon Brief, United Kingdom.

NDRC, 2014. The Order for the Construction and Operation Management of Natural Gas Infrastructure. National Development and Reform Commission, Beijing.

NDRC, 2018. Notice on rationalising gate gas price for residential users. National Development and Reform Commission, Beijing.

NEA, 2014. The Measures for the Supervision of Open Access to Oil and Gas Pipeline Network Facilities (Trial). National Energy Administration, Beijing.

Ngar-yin Mah, D., 2019. Community solar energy initiatives in urban energy transitions: A comparative study of Foshan, China and Seoul, South Korea. Energy Research and Social Science 50, 129-142.

Normann, H.E., 2015. The role of politics in sustainable transitions: The rise and decline of offshore wind in Norway. Environmental Innovation and Societal Transitions 15, 180-193.

O'Sullivan, S., 2018. China's long march to gas price freedom: Price reform in the People's Republic. Oxford Institute for Energy Studies, England.

O'Sullivan, S., 2019. China Gas: Pipeline company reform has potential to stimulate gas demand but recent price cut unlikely to have any impact. The Oxford Institute for Energy Studies, Oxford.

Olaya, Y., Dyner, I., 2017. Modelling for policy assessment in the natural gas industry, in: Kunc, M. (Ed.), System Dynamics. Palgrave Macmillan, London, pp. 329-353.

Oxenaar, S., Bosman, R., 2020. Managing the decline of fossil fuels in the fossil fuel intensive economy: The case of the Netherlands, in: Wood, G., Baker, K. (Eds.), The Palgrave Handbook of Managing Fossil Fuels and Energy Transitions. Palgrave Macmillan, Switzerland, pp. 139165.

Parra, P.A.Y., Ganti, G., Brecha, R., Hare, B., Schaeffer, M., Fuentes, U., 2019. Global and regional coal phase-out requirements of the Paris Agreement: Insights from the IPCC special report on $1.5^{\circ} \mathrm{C}$. Climate Analytics, Berlin.

Pollitt, M.G., Yang, C.-H., Chen, H., 2017. Reforming the Chinese electricity supply sector: Lessons from international experience. Energy Policy Research Group, University of Cambridge Cambridge.

PWC, 2017. New opportunities for the Guangdong-Hong Kong-Macau Greater Bay Area, Hong Kong. 
Rentier, G., Lelieveldt, H., Jan, K., G., 2019. Varieties of coal-fired power phase-out across Europe. Energy Policy 132, 620-632.

Rioux, B., Galkin, P., Murphy, F., Feijoo, F., Pierru, A., Malov, A., Li, Y., Wu, K., 2019. The economic impact of price controls on China's natural gas supply chain. Energy Economics 80, 394-410.

Roder, M., 2016. More than food or fuel. Stakeholder perceptions of anaerobic digestion and land use; a case study from the United Kingdom. Energy Policy 97, 73-81.

Sanden, B.A., Hillman, K.M.A., 2011. A framework for analysis of multi-mode interaction among technologies with examples from the history of alternative transport fuels in Sweden. Research Policy 40, 403-414.

Seba, T., 2014. Clean disruption of energy and transportation. Green Planet Ventures, Silicon Valley.

Shi, X., Rioux, B., Galkin, P., 2018. Unintended consequences of China's coal capacity cut policy. Energy Policy 113, 478-486.

Shi, X., Shen, Y., Wang, K., Zhang, Y., 2019. Capacity permit trading scheme, economic welfare and energy insecurity: Case study of coal industry in China. The Singapore Economic Review.

Shi, X., Variam, H.M.P., 2015. China's gas market liberalisation: The impact on ChinaAustralia gas trade, in: Song, L., Garnaut, R., Fang, C., Johnston, L. (Eds.), China's domestic transformation in a global context. ANU Press, Australia, pp. 137-174.

Shi, X., Wang, K., Shen, Y., Sheng, Y., Zhang, Y., 2020. A Permit Trading Scheme for Facilitating Energy Transition: A Case Study of Coal Capacity Control in China. Journal of Cleaner Production 256, 120472.

Skovgaard, J., van Asselt, H., 2018. The politics of fossil fuel subsidies and their reform: An introduction, in: Skovgaard, J., van Asselt, H. (Eds.), The politics of fossil fuel subsidies and their reform. Cambridge University Press, Cambridge.

Smink, M.M., Hekkert, M.P., Negro, S.O., 2015. Keepingsustainable innovation on a leash? Exploring incumbents' institutional strategies. Business SStrategy and the Environment 24, 86101.

Smith, A., Stirling, A., Berkhout, F., 2005. The governance of sustainable socio-technical transitions. Research Policy 34, 1491-1510.

Song, Q., Li, J., Duan, H., Yu, D., Wang, Z., 2017. Towards to sustainable energy-efficient city: A case study of Macau. Renewable and Sustainable Energy Reviews 75, 504-514.

Sovacool, B.K., 2016. How long will it take? Conceptualising the temporal dynamics of energy transitions. Energy Research and Social Science 13, 202-215.

State Council, 2019. Greater Bay Area sees improving air quality. The State Council Information Office, the People's Republic of China, China.

Su, L., 2019. A 14-year history of Ultre-High Voltage Transmission projects. ChinaPower, Beijing.

Turnheim, B., Geels, F.W., 2012. Regime destablisation as the flipside of energy transitions: Lessons from the hsitory of the British coal industry (1913-1997). Energy Policy 50, 35-49.

van Rooij, B., Zhu, Q., Li, N., Wang, Q., 2017. Centralising trends and pollution law enforcement in China. The China Quarterly 231, 583-606. 
van Ruijven, B., van Vuuren, D.P., 2009. Oil and natural gas prices and greenhouse gas emission mitigation. Energy Policy 37, 4797-4808.

Wallquist, L., Visschers, V.H.M., Siegrist, M., 2009. Lay concepts on CCS deployment in Switzerland based on qualitative interviews. International Journal of Greenhouse Gas Control $3,652-657$.

Wang, D., Liu, Y., Wang, Y., Shi, X., Song, X., 2020a. Allocation of coal de-capacity quota among provinces in China: A bi-level multi-objective combinatorial optimisation approach. Energy Economics 87, 104709.

Wang, D., Liu, Y., Wang, Y., Shi, X., Song, X., 2020b. Allocation of coal de-capacity quota among provinces in China: A bi-level multi-objective combinatorial optimization approach. Energy Economics 87, 104709.

Wang, T., Zhang, D., Ji, Q., Shi, X., 2020c. Market reforms and determinants of import natural gas prices in China. Energy 196, 117105.

Wilson, C., 2014. Unstructured interviews, in: Wilson, C. (Ed.), Interview Techniques for UX Practitioners: A User-Centered Design Method. Elsevier, Amsterdam, pp. 43-62.

WNA, 2020. Nuclear power in China. World Nuclear Association, United States.

Wong, W., Xiao, H., 2018. Twenty years of Hong Kong and Macao under Chinese rule: being absorbed under 'one country, two systems'. Public Money \& Management 38, 411-418.

Xiang, H., Kuang, Y., 2020. Who benefits from China's coal subsidy policies? A computable partial equilibrium analysis. Reosurce and Energy Economics 59, 101124.

$\mathrm{Xu}, \mathrm{C} ., 2$ 2011. The fundamental institutions of China's reforms and development. Journal of Economic Literature 49, 1076-1151.

Xu, J., Yeh, A.G.O., 2011. Political economy of regional cooperation in the Pan-Pearl River Delta, in: Yeh, A.G.O., Xu, J. (Eds.), China's Pan-Pearl River Delta: Regional Cooperation and Development. Hong Kong University Press, Hong Kong, pp. 103-124.

$\mathrm{Xu}$, J., Yeh, A.G.O., 2013. Interjurisdictional cooperation through bargaining: The case of the Guangdong-Zhuhai railway in the Pearl River Delta, China. China Quarterly 213, 130-151.

Xu, Y., Yang, D.L., 2015. The central government, in: Goodman, D. (Ed.), Handbook of the politics of China. Edward Elgar UK, pp. 76-94.

Yang, B., Jin, D., 2011. Regionally coordinated development and planning in the Pearl River Delta, in: Xu, J., Yeh, A. (Eds.), China's Pan-Pearl River Delta Regional Cooperation and Development. Hong Kong University Press, Hong Kong, pp. 81-102.

Yang, M., Sandu, S., Li, W., Khalid, M.T., 2019. Renewable energy in Australia: A wider policy discourse. Chinese Journal of Population Resources and Environment 17, 241-253.

Yuan, J., Guo, X., Zhang, W., Chen, S., Ai, Y., Zhao, C., 2019. Deregulation of power generation planning and elimination of coal power subsidy in China. Utilities Policy 57, 1-15.

Zhong, Y., 2015. Local government and politics in China: Challenges from below. Routledge.

Zhou, Y., Shan, Y., Liu, G., Guan, D., 2018. Emissions and low-carbon development in Guangdong-Hong Kong-Macao Greater Bay Area cities and their surroundings. Applied Energy 228, 168-1692. 